\title{
PENGEMBANGAN MEDIA PEMBELAJARAN KIMIA BERBASIS WEBSITE 2 APK BUILDER PADA MATERI LARUTAN ASAM BASA
}

\author{
Elmi Royani ${ }^{1 *}$, Mukhtar Haris ${ }^{2}$, Saprizal Hadisaputra ${ }^{3}$, Burhanuddin ${ }^{4}$ \\ ${ }^{1234}$ Program Studi Pendidikan Kimia, Fakultas Keguruan dan Ilmu Pendidikan, Universitas Mataram \\ Jalan Majapahit No.62 Mataram, NTB 83112, Indonesia. \\ * Coressponding Author: elmiroyani0999@gmail.com
}

Received: 20 Mei 2021

Accepted: 13 Agustus 2021

Published: 14 Agustus 2021

doi: $10.29303 /$ cep.v4i2.2670

\begin{abstract}
Abstrak
Penelitian ini merupakan penelitian dan pengembangan (Research and Development) yang memiliki tujuan untuk mengetahui validitas, kepraktisan dan keefektifan media pembelajaran kimia berbasis website 2 apk builder pada materi larutan asam basa. Desain penelitian yang digunakan adalah model pengembangan Borg dan Gall yang disederhanakan menjadi tiga tahapan yaitu studi pendahuluan, pengembangan produk awal dan evaluasi produk. Populasi dalam penelitian ini adalah 94 siswa kelas XI MIPA SMAN 1 Kopang. Sampel dalam penelitian ini adalah 30 siswa kelas XI MIPA SMAN 1 Kopang yang diambil secara acak terdiri atas 10 siswa kelas XI MIPA 1, 10 siswa kelas XI MIPA 2 dan 10 siswa kelas XI MIPA 3. Hasil penilaian validitas oleh ketiga validator menggunakan indeks Aiken diperoleh nilai $\mathrm{V}=0,89$ yang menunjukkan bahwa media pembelajaran kimia berbasis website 2 APK builder pada materi larutan asam basa sangat valid untuk diujicobakan. Hasil uji kepraktisan dapat diperoleh dari lembar observasi keterlaksanaan pembelajaran yang menunjukkan rata-rata kepraktisan untuk semua komponen sebesar $84 \%$ yang berarti bahwa media yang dikembangkan sangat praktis untuk digunakan. Sementara itu, keefektifan dapat dilihat dari respon siswa yang menunjukkan respon sangat baik dengan rata-rata keefektifan untuk semua komponen sebesar $91 \%$ yang menunjukkan bahwa media yang dikembangkan sangat efektif untuk digunakan. Secara umum, berdasarkan data tersebut dapat disimpulkan bahwa media pembelajaran kimia berbasis website 2 apk builder pada materi larutan asam basa yang dikembangkan bersifat valid, praktis, dan efektif.
\end{abstract}

Kata Kunci: pengembangan, media pembelajaran, website 2 APK builder, larutan asam basa.

\section{Development of Chemistry Learning Media Base on Website 2 APK Builder on Acid-Base Solution Material}

\begin{abstract}
The current research is a development which aims to determine the validity, practicality and effectiveness of the 2 apk builder website based chemistry learning media on acid-base solution material. The research design is based on Borg and Gall development model which is simplified into three stages, namely preliminary studies, initial product development and product evaluation. The population in this study were 94 students of class XI MIPA SMAN 1 Kopang. The sample in this study were 30 students of class XI MIPA SMAN 1 Kopang who were taken randomly consisting of 10 students of class XI MIPA 1, 10 student of class XI MIPA 2, and 10 students of class XI MIPA 3. The results of the validity assessment by the three validators using the Aiken index were obtained. The velue of $V=0,89$ which indicates that the 2 APK builder website based chemistry learning media on acid-base solution material is very valid to be tested. The practicality test results can be obtained from the learning implementation observation sheet which shows the practicality average for all components is $84 \%$, which means that the media developed is very practical to use. Meanwhile, the effectiveness can be seen from the responses students who show very good responses with an averge effectiveness for all componens of $91 \%$ which indicates that the media development is very effective for use. In general, based on these data it can be conclude that the 2 apk builder based on chemistry learning media acid-base solution material developed is valid, practical, and effective.
\end{abstract}


Keywords: Development, Learning Media, Website 2 APK Builder, Acid Base Solution.

\section{PENDAHULUAN}

Salah satu bagian dari ilmu pengetahuan alam yang memiliki karakteristik saintifik dan empirik adalah ilmu kimia. Ilmu kimia tercipta dari suatu kegiatan yang dilaksanakan secara eksperimental di laboratorium. Ilmu kimia dikategorikan dalam tiga tingkatan yaitu submikroskopik, simbolik, dan makroskopik (Hsin-kai dkk., 2000; Ariani dkk., 2020). Ratarata siswa kesulitan dalam mempelajari kimia pada tingkat submikroskopik dan simbolik dikarenakan keduanya tidak kasat mata dan memiliki sifat abstrak (Riyanto dkk., 2018; Supriadi dkk., 2021).

Larutan asam basa merupakan salah satu materi pembelajaran inti dalam kimia. Menurut Childs dan Sheehan (2007), materi larutan asam basa bisa tergolong dalam sepuluh besar topik pembelajaran kimia yang dianggap sulit oleh siswa dengan persentase sebesar 37\%. Faktor mendasar yang menyebabkannya adalah pemahaman materi larutan asam basa membutuhkan integrasi antara pemikiran skala makro dan pengamatan terhadap karakteristik fisik keasaman suatu larutan dengan pemikiran skala mikro tentang pengaruh ion $\mathrm{H}^{+}$dan skala simbolik yang dinyatakan dalam harga $\mathrm{pH}$ (Johnstone, 2006). Menurut Nakhiekh dalam (Riyanto dkk., (2018), hal inilah yang menyebabkan siswa merasa terbebani sementara alokasi waktu pembelajarannya terbatas sehingga kurang menguasai materi larutan asam basa dan melahirkan miskonsepsi dalam pembelajaran. Selain itu, di masa pandemi Covid-19 ini pembelajaran secara tatap muka ditiadakan sehingga pembelajaran dilaksanakan secara online. Sesuai dengan Surat Edaran Nomor 4 Tahun 2020 tentang Pelaksanaan Kebijakan Pendidikan dalam masa darurat penyebaran virus, Mendikbud menghimbau agar semua lembaga pendidikan tidak melakukan proses belajar mengajar secara langsung atau tatap muka, melainkan harus dilakukan secara tidak langsung atau jarak jauh (Cahyani, 2019). Oleh karena itu, dibutuhkan strategi yang tepat bagi guru selama mengajar secara online untuk meningkatkan pemahaman siswa.

$$
\text { Dengan penggunaan media }
$$

pembelajaran yang praktis serta muatan isi pembelajaran yang valid merupakan salah satu strategi yang dapat digunakan oleh guru dalam meningkatkan pemahaman siswa dalam pembelajaran kimia (Urbanger dan Kometz, 2014). Media dalam proses pembelajaran diartikan sebagai segala bentuk peralatan fisik komunikasi berupa software atau hardware yang merupakan bagian kecil dari teknologi pembelajaran yang harus diciptakan atau dikembangkan, digunakan dan dikelola untuk kebutuhan pembelajaran dalam mencapai efektivitas dan efisiensi proses pembelajaran (Arsyad, 2014). Pengembangan media pembelajaran baik untuk pendidikan formal maupun non formal, menggunakan acuan utama berupa kurikulum yang berlaku. Selain itu kemudahan pemakaian, kemenarikan dan kebermanfaatan juga harus diperhatikan. Kriteria media pembelajaran yang baik idealnya memiliki 4 faktor utama, yaitu relevansi, kemudahan, kemenarikan, dan kemanfaatan (Mulyanta, 2009).

Saat ini, dengan adanya perkembangan teknologi memudahkan guru dalam membuat dan merancang media pembelajaran sesuai dengan kebutuhan siswa (Chuang, 2014). Salah satu media pembelajaran yang sesuai dengan kebutuhan siswa adalah media pembelajaran berlandas website 2 apk builder yang merupakan software pengubah file media pembelajaran dari powerpoint yang dikombinasikan dengan ispiring suite 8 menjadi aplikasi android (Hadi, 2020). Media pembelajaran ini merupakan alternatif yang memiliki karakteristik yang unik, yaitu dapat digunakan dimana saja dan kapan saja, didukung dengan visualisasi yang menarik karena dapat diubah menjadi aplikasi android. Kondisi ini sesuai dengan pendapat Sadiman (2010) yang menyebutkan bahwa peserta didik dapat belajar secara tidak langsung dengan aktif berinteraksi menggunakan media atau sumber belajar lainnya, sehingga proses belajar dapat dilakukan kapan saja dan dimana saja siswa berada. Penggunaan alternatif belajar seperti media ini bagi siswa diharapkan dapat memudahkan mereka dalam mengikuti pembelajaran kimia.

Berdasarkan hasil wawancara dengan seorang guru kimia SMAN 1 Kopang Lombok Tengah yang mengatakan bahwa "kendalanya dalam mengajar materi kimia termasuk di dalamnya materi larutan asam basa adalah 
sebagian besar siswa memiliki semangat belajar yang kurang jika hanya dijelaskan di dalam kelas akan tetapi semangat belajar mereka sangat luar biasa jika belajarnya dengan menggunakan metode praktikum dan juga dengan media pembelajaran yang dibuat lebih menarik'. Dalam pembelajaran kimia materi larutan asam basa, media pembelajaran berbasis website 2 apk builder dapat dimanfaatkan juga untuk praktikum sederhana secara digital pada penentuan sifat larutan dengan kertas lakmus. Praktikum digital ini tidak menggunakan alat dan bahan secara nyata sehingga lebih praktis yang dikemas dalam bentuk video pada aplikasi android. Berdasarkan paparan di atas maka peneliti mengembangkan media pembelajaran pada salah satu materi kimia yaitu larutan asam basa yang berlandas website 2 apk builder.

\section{METODE PENELITIAN}

Kegiatan penelitian ini dilaksanakan dari Bulan Februari sampai April 2021. Penelitian ini termasuk penelitian dan pengembangan (Research and Development) yang mengadaptasi model pengembangan Borg dan Gall. Model pengembangan ini disederhanakan menjadi tiga tahapan yaitu studi pendahuluan, pengembangan produk awal, dan evaluasi atau penilaian produk (Lubis dan Ikhsan, 2015). Media pembelajaran yang dikembangkan dalam penelitian ini adalah media berlandas website 2 apk builder pada salah satu materi kimia yaitu larutan asam basa.

Penelitian ini bertujuan menentukan bagaimana validitas, kepraktisan dan keefektifan media pembelajaran yang dikembangkan. Dalam penelitian ini jumlah populasinya adalah 94 siswa kelas XI MIPA Sekolah Menengah Atas Negeri 1 Kopang. Teknik pengambilan sampel siswa adalah dengan menggunakan teknik Simple Rendom Sampling. Teknik ini merupakan pengambilan anggota sampel dari populasi dilakukan secara acak tanpa memperhatikan strata yang ada di dalam populasi (Wijayanti dkk., 2015). Dalam penelitian ini total sampel yang digunakan peneliti adalah 30 siswa yang diambil secara acak diantaranya 10 siswa kelas XI MIPA 1, 10 siswa kelas XI MIPA 2, dan 10 siswa kelas XI MIPA 3.

Penelitian ini menggunakan instrumen lembar validasi media pembelajaran, lembar observasi keterlaksanaan pembelajaran serta angket respon siswa. Lembar validasi media pembelajaran digunakan untuk mengetahui tingkat validitas media pembelajaran yang dianalisis menggunakan statistik Aiken's V yang dinilai oleh tiga orang validator. Lembar observasi keterlaksanaan pembelajaran menggunakan media pembelajaran dianalisis menggunakan rumus perhitungan persentase untuk menentukan kepraktisan. Angket respon siswa juga dianalisis menggunakan rumus perhitungan persentase untuk menentukan keefektifan media pembelajaran yang dikembangkan.

\section{HASIL DAN PEMBAHASAN}

Penelitian ini mengembangkan sebuah media pembelajaran berlandas website 2 apk builder pada salah satu materi kimia yaitu larutan asam basa. Penelitian ini bertujuan untuk menghasilkan produk media pembelajaran yang memenuhi kriteria valid, praktis, dan efektif melalui uji validitas, uji kepraktisan dan uji keefektifan dengan metode penelitian dan pengembangan menurut Borg and Gall yang disederhanakan menjadi tiga tahapan yaitu studi pendahuluan, pengembangan produk awal, dan evaluasi produk.

\section{Tahap Studi Pendahuluan}

Tahapan pertama dalam studi pendahuluan peneliti melakukan analisis kebutuhan yang dibagi menjadi dua tahapan yaitu studi pustaka dan studi lapangan. Pada tahap studi pustaka, peneliti mencari beberapa sumber seperti jurnal yang relevan dengan penelitian yaitu jurnal yang membahas tentang penggunaan media pembelajaran yang dapat menarik minat belajar siswa salah satunya dengan memanfaatkan teknologi sehingga siswa lebih tertarik mempelajari kimia menggunakan media pembelajaran tersebut. Selain itu, diketahui bahwa materi larutan asam basa menurut Childs dan Sheehan tergolong dalam 10 besar topik pembelajaran yang dianggap sulit, sehingga dengan penggunaan media berlandas website 2 apk builder menurut peneliti dapat memudahkan siswa dalam mempelajari larutan asam basa di mana saja dan kapan saja siswa berada. Tahap kedua dalam studi pendahuluan adalah tahap studi lapangan, peneliti melakukan studi lapangan dengan mewawancara guru kimia SMAN 1 Kopang Lombok Tengah yang mengajar di kelas XI MIPA. Berdasarkan hasil wawancara tersebut dikatakan bahwa siswa memiliki semangat belajar kimia yang kurang jika hanya dijelaskan di dalam kelas akan tetapi semangat belajar siswa sangat luar biasa jika belajarnya dengan menggunakan metode 
praktikum dan juga dengan media pembelajaran yang dibuat lebih menarik. Selain itu, di masa pandemi covid-19 ini dibutuhkan strategi bagi guru agar siswa tetap memahami pembelajaran secara daring. Penggunaan media berlandas website 2 apk builder dapat dijadikan sebagai salah satu solusi bagi guru dalam mengajar materi larutan asam basa di masa pandemi covid-19 ini. Hal ini dikarenakan media pembelajaran ini dapat diunduh pada android masing-masing siswa yang juga dilengkapi dengan praktikum sederhana secara digital pada penentuan sifat larutan asam dan larutan basa.

\section{Pengembangan Produk Awal}

Tahap pengembangan produk awal merupakan tahap yang dilakukan peneliti untuk menghasilkan produk. Tahap ini dilakukan peneliti setelah melakukan studi pendahuluan yang terdiri atas tiga tahapan dalam proses pengembangan media pembelajaran awal sebelum diujicobakan. Tiga tahapan tersebut dimulai dari penyusunan format media pembelajaran, tujuan penyusunan format media pembelajaran dimaksudkan agar media yang dikembangkan memiliki format atau rancangan yang tepat dan terarah.

Langkah selanjutnya setelah format media pembelajaran ditentukan, peneliti mulai membuat media pembelajaran awal sebelum diujicobakan. Pembuatan media pembelajaran dibuat dengan menggunakan powerpoint yang dilengkapi dengan ispiring suite 8 selanjutnya diubah menjadi aplikasi android menggunakan aplikasi Website 2 APK (Application Package Kit) Builder. Dalam penyusunan portofolio media pembelajaran sampai media pembelajaran selesai dibuat peneliti juga melakukan perbaikan sesuai saran dan arahan yang diberikan pembimbing selama kegiatan pembuatan media pembelajaran dilaksanakan. Semua portofolio media pembelajaran yang dihasilkan selama proses ini disebut $d r a f$. Rancangan isi dari draf 1 pembuatan media pembelajaran diantaranya terdiri atas menu mulai, judul media pembelajaran, menu petunjuk, menu kompetensi, materi pemblajaran, menu quiz, menu referensi serta menu profil.

Setelah rancangan media pembelajaran ditentukan, peneliti mulai menyusun media pembelajaran yang dihasilkan pada draf 1 sebelum diujicobakan. Pada tahap ini, peneliti menyusun media pembelajaran yang terdiri atas cover dan isi media. Cover media pembelajaran terdiri atas judul media pengembangan, nama penulis, dan institusi peneliti. Lambang institusi peneliti terletak pada bagian tengah antara judul media pembelajaran dengan nama penulis. Cover media pembelajaran juga dilengkapi dengan gambar home yang merupakan tombol untuk menuju menu selanjutnya.

Selanjutnya isi media pembelajaran dirancang untuk membantu siswa dalam memahami materi pembelajaran kimia yaitu larutan asam basa. Pada bagian materi juga dilengkapi dengan quiz sebagai evaluasi bagi siswa setelah mempelajari larutan asam basa menggunakan media pembelajaran. Isi dari media pembelajaran yang dikembangkan dapat dilihat pada gambar 1 .

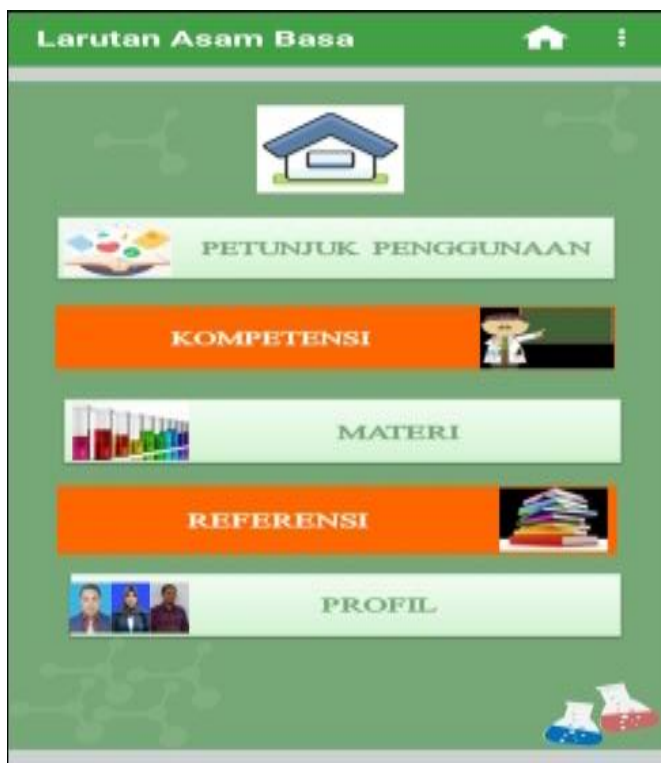

Gambar 1. Isi Media Pembelajaran

\section{Evaluasi Produk}

Tahap ini bertujuan untuk menghasilkan draf 2 yang telah direvisi oleh validator atau para ahli dan telah diujicobakan kepada siswa sehingga valid, praktis, dan efektif untuk digunakan sebagai salah satu media belajar pada materi larutan asam basa. Instrumen penelitian yang digunakan yaitu lembar validasi media, lembar observasi keterlaksanaan pembelajaran, serta angket respon siswa. Lembar validasi media digunakan untuk mengetahui tingkat validitas media pembelajaran yang dikembangkan. Lembar validasi media pembelajaran terdiri atas aspek kegrafikan, aspek penyajian, aspek kelayakan, dan aspek kebahasaan dengan empat pilihan kategori yaitu sangat baik, baik, cukup baik, dan kurang baik. Instrumen yang baik hendaknya harus memenuhi dua persyaratan yang penting yaitu validitas daan reliabilitas. Validasi dilakukan 
Chemistry Education Practice, 2 (1), 2019 - 198

Royani, Haris, Hadisaputra, Burhanuddin

oleh tiga orang validator. Hasil validasi ini akan menentukan validitas media pembelajaran yang dikembangkan. Penilaian validator disertai kolom komentar sebagai catatan perbaikan media pembelajaran. Validator dalam penelitian ini adalah 1 orang dosen kimia FKIP Universitas Mataram dan 2 orang guru kimia SMAN 1 Kopang.

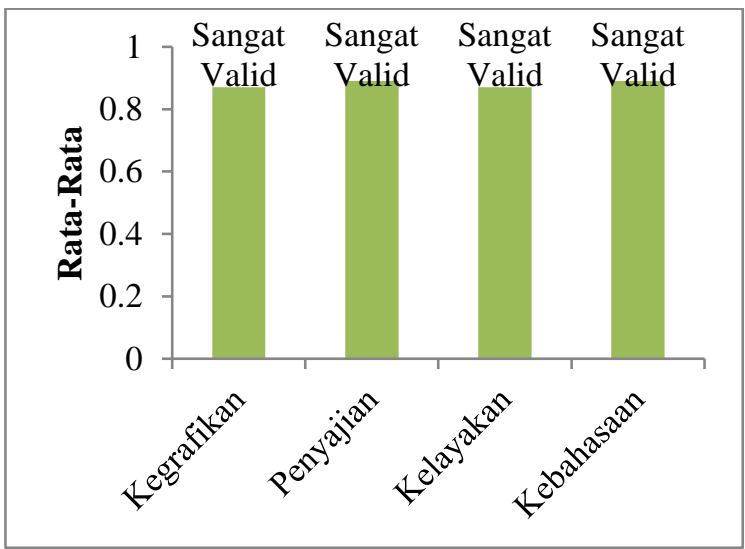

Gambar 2. Validitas Media Pembelajaran

Berdasarkan gambar 2 diketahui bahwa validitas media pembelajaran kimia yang dianalisis menggunakan indeks Aiken $\mathrm{V}$ pada aspek kegrafikan nilai $\mathrm{V}=0,87$ dengan kategori sangat valid, aspek penyajian diperoleh nilai $\mathrm{V}=$ 0,89 dengan kategori sangat valid, aspek kelayakan diperoleh nilai $\mathrm{V}=0,87$ dengan kategori sangat valid, dan aspek kebahasaan diperoleh nilai $\mathrm{V}=0,89$ dengan kategori sangat valid. Sehingga dari hasil uji validitas media pembelajaran yang telah dikembangkan berdasarkan empat aspek tersebut diperoleh ratarata nilai $\mathrm{V}$ sebesar 0,89 dengan kategori sangat valid.

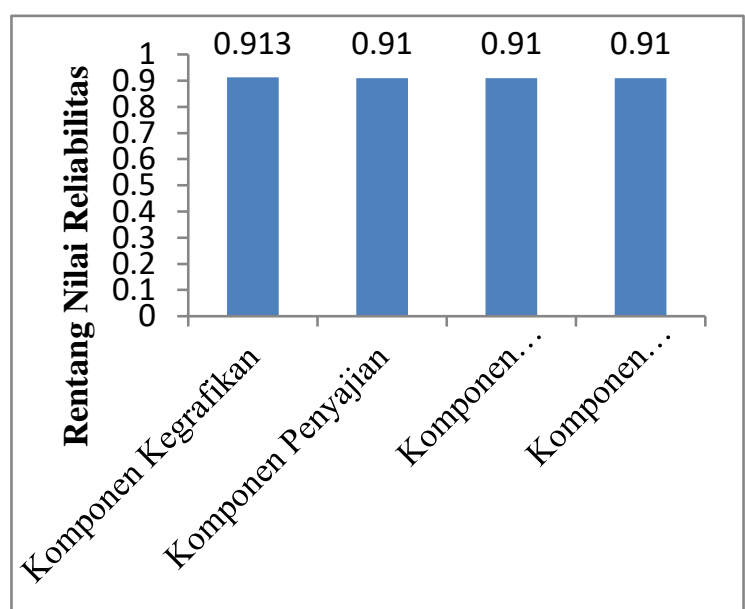

Gambar 3. Reliabilitas Media Pembelajaran

Setelah dilakukan uji validitas selanjutnya peneliti melakukan uji reliabilitas pada semua komponen yaitu komponen kegrafikan, komponen penyajian, komponen kelayakan isi dan komponen kebahasaan. Berdasarkan gambar 3, rata-rata nilai relabilitas untuk semua komponen sebesar 0,911 atau $91,1 \%$. Sehingga dapat ditarik kesimpulan bahwa produk media pembelajaran yang dihasilkan telah terbukti reliabel dan baik untuk digunakan dalam pembelajaran kimia. Hal ini dikarenakan media pembelajaran tersebut memiliki nilai Percantage of agreement yang $>75 \%$.

Produk media pembelajaran kimia yang telah memenuhi kriteria sangat valid dan reliabel untuk digunakan selanjutnya dilakukan uji kepraktisan. Uji kepraktisan dilakukan observer dengan mengamati proses pembelajaran menggunakan media pembelajaran pada 30 siswa sampel. Uji yang dilakukan terdiri atas tiga kegiatan yang terdapat pada lembar observasi keteraksanaan pembelajaran diantaranya kegiatan pendahuluan, inti, dan penutup. Grafik kepraktisan dapat dilihat pada gambar 4.

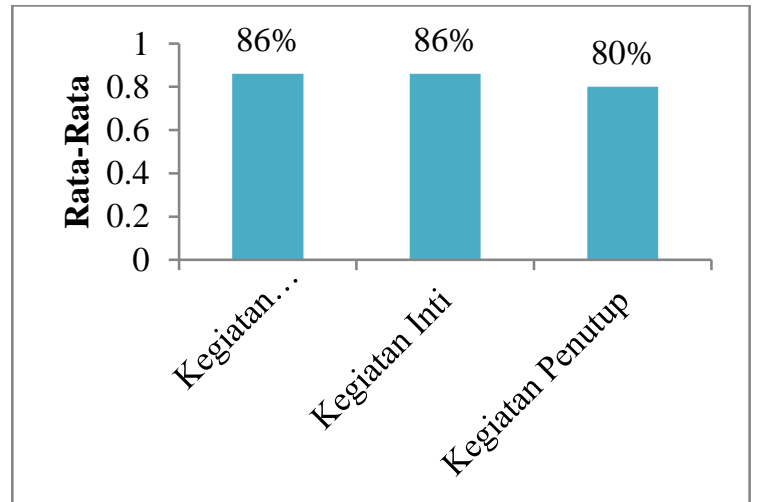

Gambar 4. Kepraktisan Media Pembelajaran

Berdasarkan gambar 5 analisis lembar observasi keterlaksanaan pembelajaran yang telah dilakukan observer menggunakan indeks kepraktisan diketahui bahwa pada kegiatan pendahuluan diperoleh persentase sebesar $86 \%$, kegiatan inti juga diperoleh persentase sebesar $86 \%$, dan kegiatan penutup dengan persentase sebesar $80 \%$. Sehingga hasil uji kepraktisan media pembelajaran yang telah dikembangkan berdasarkan tiga kegiatan yang telah diamati observer diperoleh rata-rata kepraktisan sebesar $84 \%$ yang tergolong dalam kategori sangat praktis.

Uji terakhir yaitu uji keefektifan. Uji ini dilakukan setelah media pembelajaran dinyatakan valid dan praktis. Uji keefektifan yang dilakukan peneliti terhadap 30 siswa 


\section{Chemistry Education Practice, 2 (1), 2019 - 199}

Royani, Haris, Hadisaputra, Burhanuddin

sampel terdiri atas beberapa aspek, yaitu aspek kemenarikan media pembelajaran, aspek kemudahan penggunaan media pembelajaran, dan aspek manfaat media pembelajaran. Grafik keefektifan dapat dilihat pada gambar 5 .

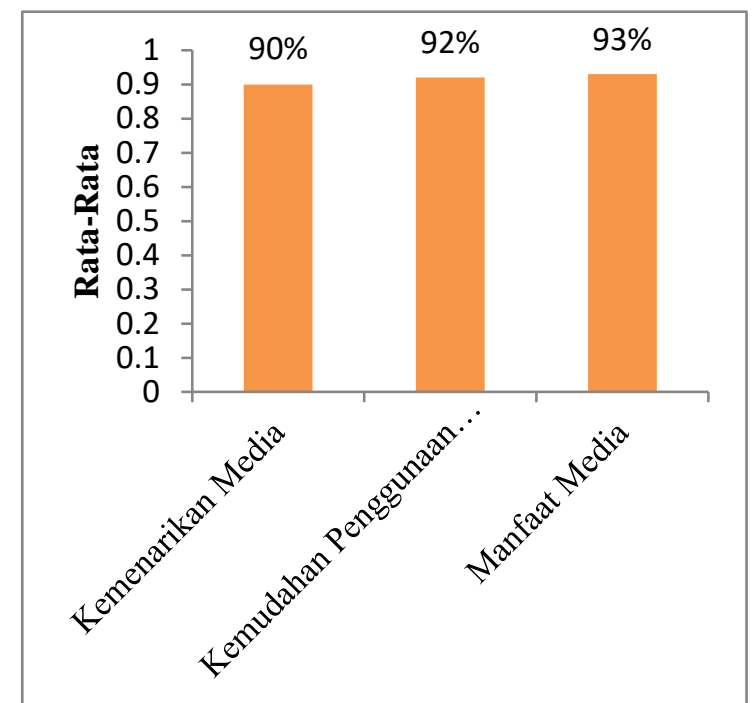

Gambar 5. Keefektifan Media Pembelajaran

Pada gambar 5 respon siswa terhadap produk media pembelajaran yang dikembangkan berdasarkan indeks keefektifan diperoleh persentase kemenarikan media, kemudahan penggunaan media, dan kemenarikan media secara berturut-turut yaitu $90 \%, 92 \%$, dan $93 \%$. Sehingga hasil uji keefektifan media pembelajaran kimia yang telah dikembangkan berdasarkan tiga komponen tersebut memiliki nilai rata-rata sebesar $91 \%$ yang tergolong dalam kategori sangat efektif.

Setelah dilakukan uji validitas menggunakan lembar validasi oleh 3 orang validator, uji kepraktisan menggunakan lembar observasi keterlaksanaan pembelajaran oleh observer, serta uji keefektifan menggunakan angket respon siswa, maka diperoleh kesimpulan bahwa produk media pembelajaran yang dikembangkan telah dinyatakan sangat valid, sangat praktis dan sangat efektif.

\section{SIMPULAN}

Produk media pembelajaran yang telah dikembangkan menggunakan model Borg dan Gall yaitu studi pendahuluan, pengembangan produk awal dan evaluasi produk telah berada pada kategori sangat valid, sangat praktis dan sangat efektif.

\section{SARAN}

Penelitian ini sudah dilaksanakan sampai uji keefektifan dengan jumlah sampel terbatas sebanyak 30 siswa. Oleh karena itu, diharapkan peneliti selanjutnya dapat melakukan uji keefektifan dengn uji coba skala besar. Selain itu, diharapkan peneliti selanjutnya bisa membuat media pembelajaran serupa pada setiap materi pembelajaran sehingga siswa lebih tertarik dalam mempelajari kimia.

\section{DAFTAR PUSTAKA}

Ariani, S., Effendy, E., \& Suharti, S. (2020). Model Mental Mahasiswa Pada Fenomena Penghilangan Karat Melalui Elektrolisis. Chemistry Education Practice, 3(2), 5562.

Arsyad, A. (2014). Media Pembelajaran. Jakarta: PT. Raja Grafindo Persada. Cahyani, A., Listiana, I. D., \& Larasati, S. P. D. (2020). Motivasi Belajar Siswa SMA pada Pembelajaran Daring di Masa Pandemi Covid-19. IQ (Ilmu Al-qur'an): Jurnal Pendidikan Islam, 3(01), 123-140.

Childs dan Sheehan. (2007). What Chemistry Topics do Student Find Difficult?. Proceedings of the $2^{\text {nd }}$ European Variety in Chemistry Education. Prague: Charles University.

Chuang, Y. T. (2014). Increasing Learning Motivation and Student Engagment Through the Thechnology-supported Learning Environment. Creative Education. 5: 1969-1987.

Hadi, N. (2020). Powerspring sebagai Solusi Inovatif Pembelajaran yang Asyik dan Menyenangkan di Rumah Selama Pandemi Covid-19 bagi Siswa SD. Jurnal Pendidikan Dasar. 2(1). 143-154.

Hsin-kai, W., Krajick, S., \& Eliot, S. (2000). Promoting Conceptual Understanding of Chemical Representation: Students Use of a Visualization Tool in Classroom. Paper. University of Michigan.

Johnstone, A.H. (2006). Chemical Education Research in Glasgow in Generation of Visualization, in Allen G. (ed). Applied Spatial Cognition: from Research to cognitive technology. Mahwah, NJ: Erlbaum. 53-74.

Lubis, I. R., \& Ikhsan, J. (2015). Pengembangan media pembelajaran kimia berbasis android untuk meningkatkan motivasi 


\section{Chemistry Education Practice, 2 (1), 2019 - 200}

Royani, Haris, Hadisaputra, Burhanuddin

belajar dan prestasi kognitif peserta didik

SMA. Jurnal Inovasi Pendidikan IPA,

1(2), 191-201.

Mulyanta. (2009). Tutorial Membangun Media

Interaktif Media Pembelajaran.

Yogyakarta: Universitas Atma Jaya.

Riyanto, N., Asmara, A. P., \& Purbalingga, B. (2018). Penilaian Kualitas Media Audio

Visual Tentang Karakteristik Larutan

Asam Basa untuk Siswa SMA/MA.

Jurnal Pendidikan Sains, 6(1), 73-85.

Sadiman. (2010). Media Pendidikan

'Pengertian, Pengembangan dan

Pemanfaatannya". Jakarta: PT. Grafindo Persada.

Supriadi, Wildan, Hakim, A., Savalas, L. T., \& Haris, M. (2021). Model Mental dan Kemampuan Spasial Mahasiswa Tahun Pertama dan Ketiga Pendidikan Kimia di Universitas Mataram. Jurnal Pijar Mipa, 14(2).

Urbanger, M dan Kometz, A. (2014). Reasearch

Theory and Practice in Chemistry

Didactics. Proceedings of the $23^{\text {nd }}$

International Conference on Chemistry

Education. Hradec Kralove: Universitas of Hradec Kralove. 182-192.

Wijayanti, D., Saputro, S., \& Nurhayati, N. D. (2015). Pengembangan media lembar kerja siswa (lks) berbasis hierarki konsep untuk pembelajaran Kimia kelas x pokok bahasan pereaksi pembatas. Jurnal

Pendidikan Kimia, 4(2), 15-22. 